University of Nebraska - Lincoln

DigitalCommons@University of Nebraska - Lincoln

1983

\title{
Chemical Composition of Ground Water and the Locations of Permeable Zones in the Yucca Mountain Area, Nevada
}

Larry Benson

J. H. Robison

R. K. Blankennagel

A. E. Ogard

Follow this and additional works at: https://digitalcommons.unl.edu/usgspubs

Part of the Geochemistry Commons, Geology Commons, Geomorphology Commons, Hydrology Commons, and the Other Earth Sciences Commons

This Article is brought to you for free and open access by the US Geological Survey at DigitalCommons@University of Nebraska - Lincoln. It has been accepted for inclusion in Publications of the US Geological Survey by an authorized administrator of DigitalCommons@University of Nebraska - Lincoln. 


\title{
UNITED STATES DEPARTMENT OF THE INTERIOR
}

GEOLOGICAL SURVEY

\begin{abstract}
CHEMICAL COMPOSITION OF GROUND WATER AND THE LOCATIONS OF PERMEABLE ZONES IN THE YUCCA MOUNTAIN AREA, NEVADA
\end{abstract}

by

L. V. Benson ${ }^{1}$, J. H. Robison ${ }^{1}$, R. K. Blankennage $1^{1}$, and A. E. Ogard ${ }^{2}$

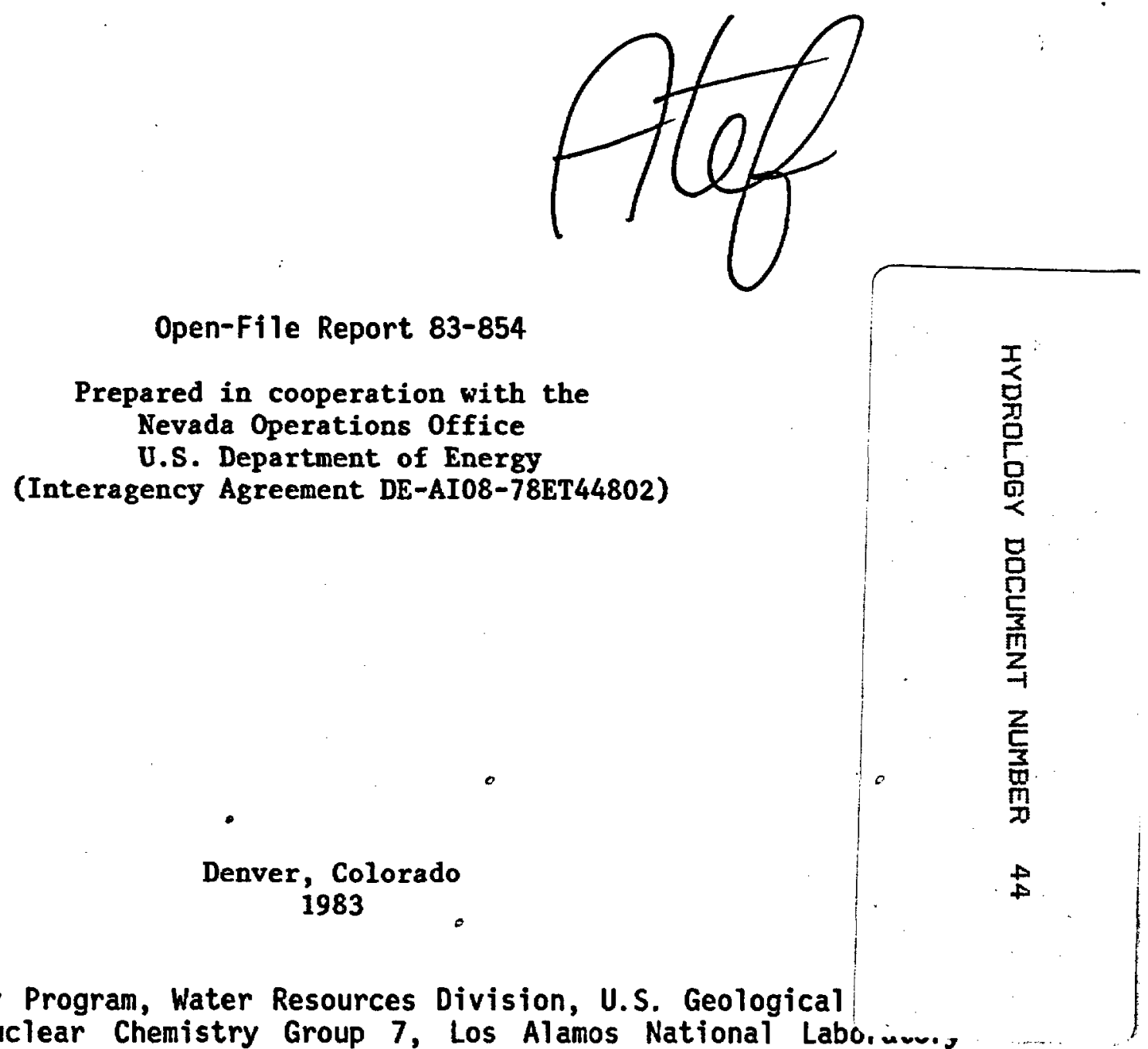

1 Nuclear Hydrology Program, Water Resources Division, U.S. Geological

Inorganic and Nuclear Chemistry Group 7, Los Alamos National Labo.u.... s 


\author{
UNITED STATES DEPARTMENT OF THE INTERIOR \\ JAMES G. WATT, Secretary \\ GEOLOGICAL SURVEY \\ Dallas L. Peck, Director
}

For additional information write to:

Chief, Nuclear Hydrology Program Water Resources Division U.S. Geological Survey Box 25046, Mail Stop 416 Denver Federal Center Denver, C0 80225
Copies of this report can be puchased from:

Open-File Services Section Western Distribution Branch U.S. Geological Survey Box 25425, Federal Center Denver, CO 80225 (Telephone: [303] 234-5888) 


\author{
UNITED STATES \\ DEPARTMENT OF THE INTERIOR \\ GEOLOGICAL SURVEY \\ CHEMICAL COMPOSITION OF GROUND WATER AND THE LOCATIONS OF \\ PERMEABLE ZONES IN THE YUCCA MOUNTAIN AREA, NEVADA
}

\title{
by
}

L. V. Benson ${ }^{1}$, J. H. Robison ${ }^{1}$, R. K. Blankennagel ${ }^{1}$, and A. E. Ogard ${ }^{2}$

${ }^{1}$ Nuclear Hydrology Program, U.S. Geological Survey, Denver, Colorado

${ }^{2}$ Inorganic and Nuclear Chemistry Group 7, Los Alamos National Laboratory, Los Alamos, New Mexico 


\section{CONTENTS}

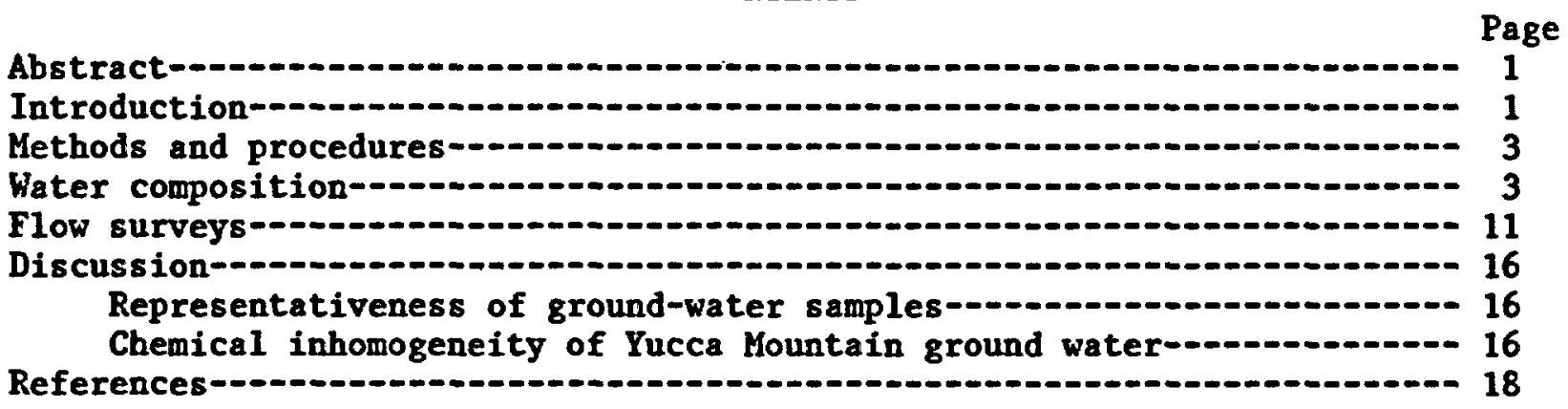

\section{ILLUSTRATIONS}

Figure 1. Map of the Nevada Test Site and vicinity showing the area of investigation and the Yucca Mountain exploratory block--- 2

2. Map showing selected drill-hole locations on and near the Yucca Mountain exploratory block-........ 4

3. Diagram showing a typical well construction (well USW H-5)-..- 5 4-6. Graphs showing:

4. Results of borehole-flow surveys in wells UE-25b非 and USW H-1-_..... 6

5. Results of borehole-flow surveys in wells USW $\mathrm{H}-4$ and USW G-4-. 7

6. Results of borehole-flow surveys in wells USW $\mathrm{H}-5$ and USW H-6-_..- 8

7. Trilinear diagrams of relative cation and anion concentrations (equivalent fractions) of ground water from the Yucca Mountain area-_-_- 12 Maps showing:

8. Sodium, potassium, calcium, and magnesium concentrations, in milligrams per liter, in ground water from the Yucca Mountain a rea-...... 13

9. Bicarbonate, sulfate, chloride, and fluoride concentrations, in milligrams per liter, in ground water from the Yucca Mountain area-... 14

10. Del oxygen-18 $\left(\delta^{18} 0\right)$, del deuterium $(\delta \mathrm{D})$ del carbon-13 $\left(\delta^{13} \mathrm{C}\right)$, and uncorrected carbon-14 (14 C) ages for ground water from the Yucca Mountain area-_... 15

11. Chart showing vertical distribution of permeable zones in selected wells in the Yucca Mountain area--.-.-- 17

12. Graph showing plot of drilling-fluid contamination as a function of lithium concentration-_... 18

\section{TABLE}

Table 1. Chemical composition of water samples obtained from wells in 
CONVERSION TABLE

Multiply metric unit

millimeter (mm)

meter ( $m$ )

kilometer ( km)

liter (L)

liter per second $(\mathrm{L} / \mathrm{s})$ by

0.03937

3.281

0.6214

0.2642

15.85
To obtain inch-pound unit

inch (in.)

foot $(\mathrm{ft})$

mile (mi)

gallon (gal)

gallon per minute

(gal/min) 
CHEMICAL COMPOSITION OF GROUND WATER AND THE LOCATIONS OF

PERMEABLE ZONES IN THE YUCCA MOUNTAIN AREA, NEVADA

by L. V. Benson, J. H. Robison, R. K. Blankennagel

and A. E. Ogard

\begin{abstract}
Ten wells in the Yucca Mountain area of southern Nevada have been sampled for chemical analysis. Samples were obtained during pumping of water from the entire well bore (composite sample) and in one instance by pumping water from a single isolated interval in well UE-25b\#1. Sodium is the most abundant cation and bicarbonate the most abundant anion in all water samples. Although the general chemical compositions of individual samples are similar, there are significant differences in uncorrected carbon-14 age and in inorganic and stable-isotope composition. Flow surveys of seven wells performed using iodine-131 as a tracer indicate that ground-water production is usually from one or more discrete zones of permeability.
\end{abstract}

\title{
INTRODUCTION
}

The Yucca Mountain site in southern Nevada (fig. 1) is being investigated as a possible repository for the disposal of high-level nuclear wastes. The site is underlain by partially altered volcanic tuffs (Caporuscio and others, 1982) that probably extend to depths greater than $3,000 \mathrm{~m}$. If approved, the repository most likely will ,be excavated within the unsaturated zone, 150 to $300 \mathrm{~m}$ above the water-table surface. There is concern that radionuclides, once leached from the stored wastes, will eventually reach the saturated zone where they will be transported in the ground-water system from the repository site to the accessible environment. In order to understand the types and magnitudes of chemical processes that affect the potential movement of radionuclide species, compositional characterization of ground-water samples from the Yucca Mountain area has been initiated. This report summarizes preliminary findings to date. The authors wish to acknowledge the assistance of Charles L. Washington and William J. Oatfield, U.S. Geological Survey, who performed most of the sampling and onsite analysis procedures. 


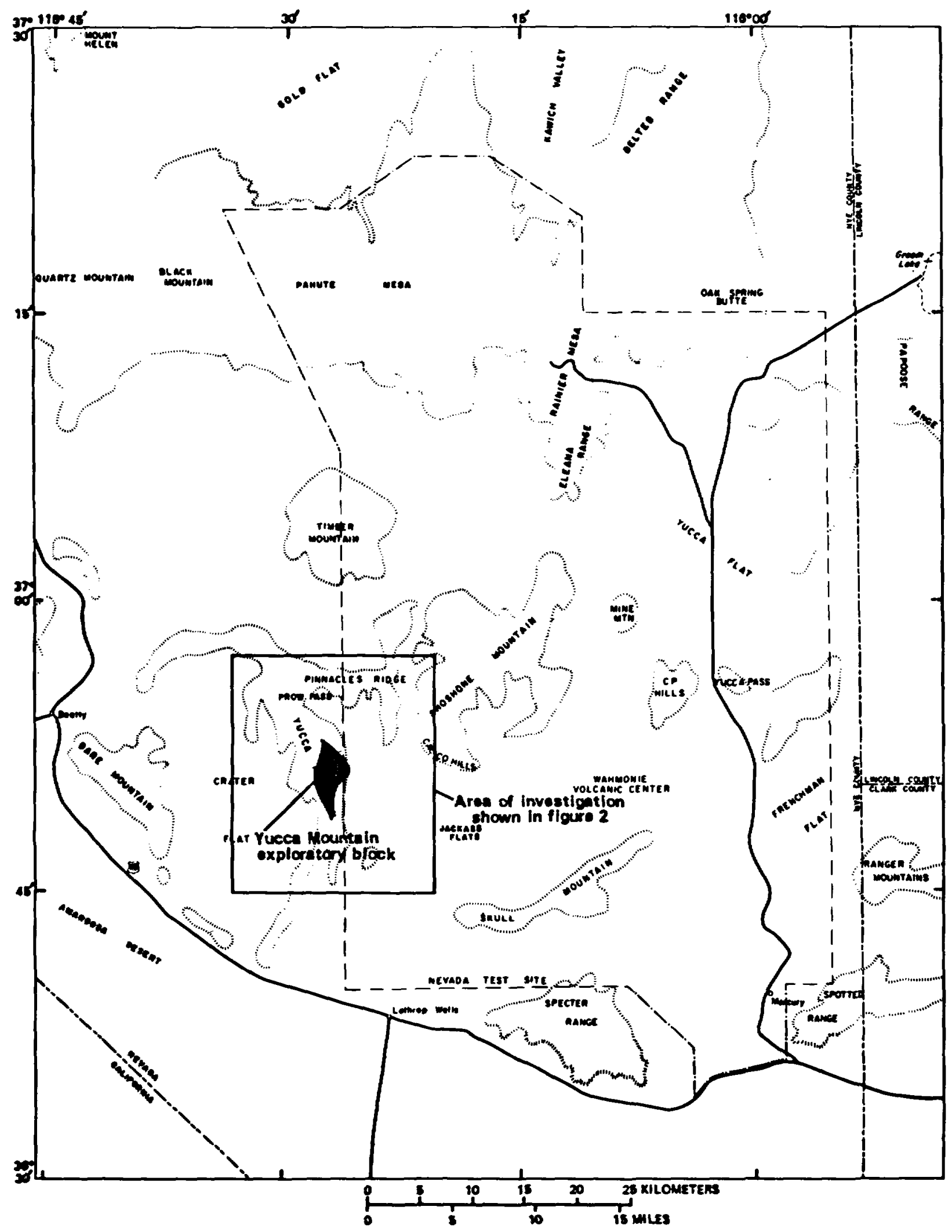

Figure 1.--Nevada Test Site and vicinity showing the area of investigation and the Yucca Mountain exploratory block. 


\section{METHODS AND PROCEDURES}

Drilling fluid was composed of local ground water to which "soap" (linear olefin sulfonate or sodium benzoyl sulfonate plus isopropyl alcohol) was added. This addition generated foam that aided in removal of cuttings from the hole. For drilling of well USW H-6 (fig. 2), the source of ground water was well USW VH-1; for all other wells, the ground-water source was well J-13. A tracer consisting of about $20 \mathrm{mg} / \mathrm{L}$ (milligrams per liter) of lithium chloride was added to drilling fluid for all wells except USW $\mathrm{H}-1$.

Wells were cased from the surface to depths ranging from 50 to $90 \mathrm{~m}$ below the water table. Casing extending from the land surface to a depth of about $100 \mathrm{~m}$ in the unsaturated zone was cemented to the surface. The bottom $9 \mathrm{~m}$ of casing penetrating the saturated zone also was cemented. That part of the saturated zone penetrated by casing was perforated. The typical well construction is shown in figure 3.

Wells were pumped for 2 to 13 days before water samples were obtained for chemical analysis. During pumping, water was monitored routinely for temperature, specific conductance, $\mathrm{pH}$, and lithium concentration. An effort was made to sample after the temperature, specific conductance, and pH became relatively stable and the lithium concentration had decreased to a value near that considered typical of natural formation water $[50$ to $100 \mu \mathrm{g} / \mathrm{L}$ (micrograms per liter)]. Alkalinity usually was measured onsite. Water samples were filtered onsite using a nitrogen-pressured, stainless-steel vessel containing a $0.45 \mu \mathrm{m}$ (micrometer) membrane. The filtered samples were collected in polyethylene bottles that previously had been washed with high-purity nitric acid and rinsed with distilled-deionized water. Samples to be analyzed for cations were acidified with high-purity nitric acid to a pH of about 1 . Laboratory procedures for inorganic substances are those detailed in Brown and others (1970). Methods for collection of water samples for determination of tritium and radiocarbon are given in Thatcher and others (1977). Methods for collection of water samples for analysis of the stable isotopes of hydrogen, oxygen, and carbon were provided by R. J. Pickering (U.S. Geological Survey, written commun., 1981).

Borehole-flow surveys were conducted in all wells on or near the Yucca Mountain exploratory block (fig. 2). The surveys were done by injecting an aqueous solution of ${ }^{131}$ I (iodine-131) into the borehole fluid while pumping the well. The rate of movement of the ${ }^{131} \mathrm{I}$ slug was determined using two gamma detectors positioned above the ${ }^{131} \mathrm{I}$ tracer injector. The arrival times of ${ }^{131} \mathrm{I}$ at the detectors are used with the average hole size calculated from a caliper-log survey to determine flow rates at selected depths in the borehole. A more detailed discussion of this technique is presented in Blankennagel (1967). Results of the borehole-flow surveys are depicted in figures 4 to 6 and discussed in the section "Flow Surveys."

\section{WATER COMPOSITION}

The chemical composition of samples taken from wells shown in figure 3 are listed in table 1. Data for we $11 \mathrm{~s} \mathrm{~J}-12$ and $\mathrm{J}-13$ are from Claassen (1973). 


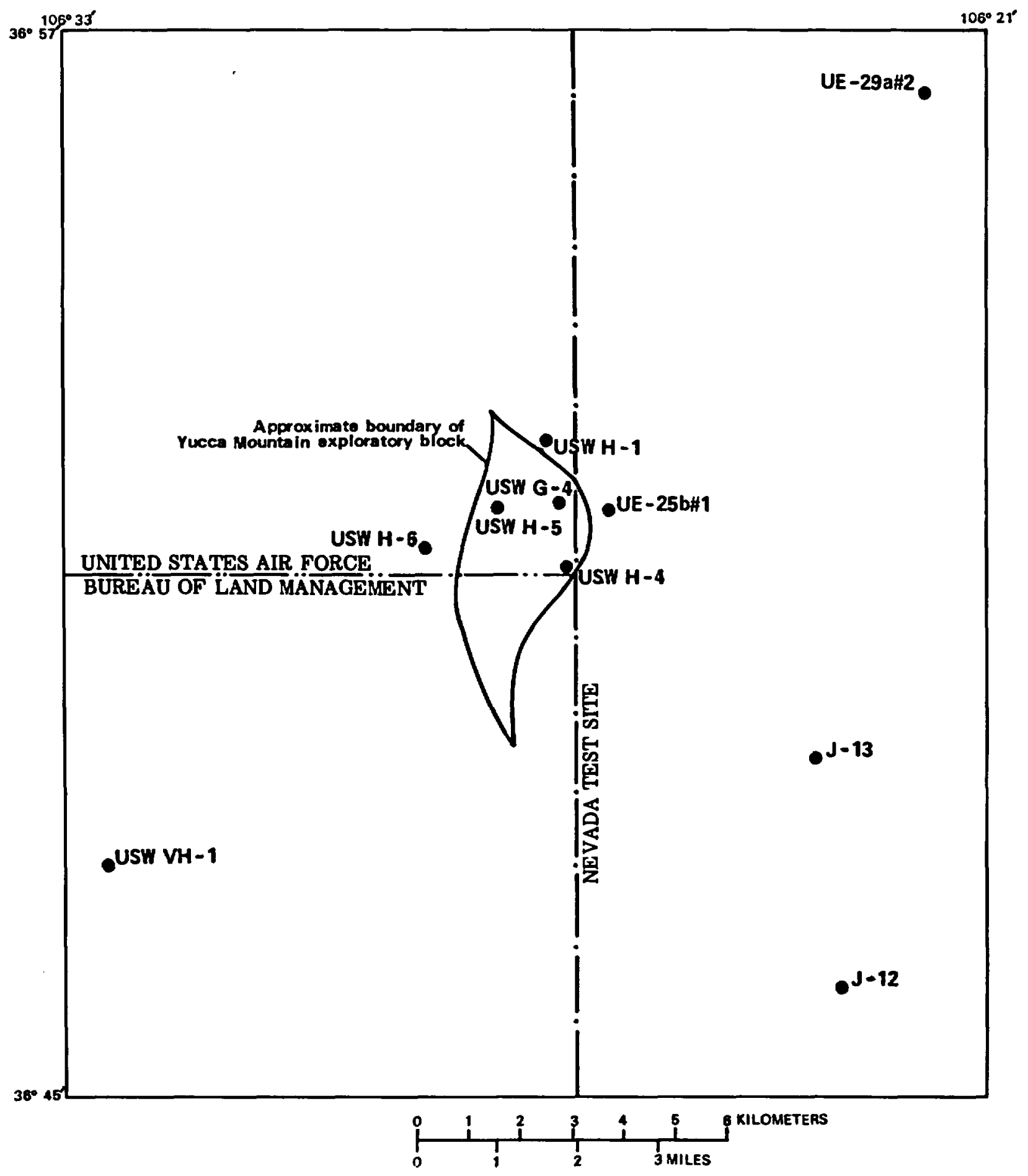

Figure 2.--Selected drill-hole locations on and near the Yucca Mountain exploratory block. 


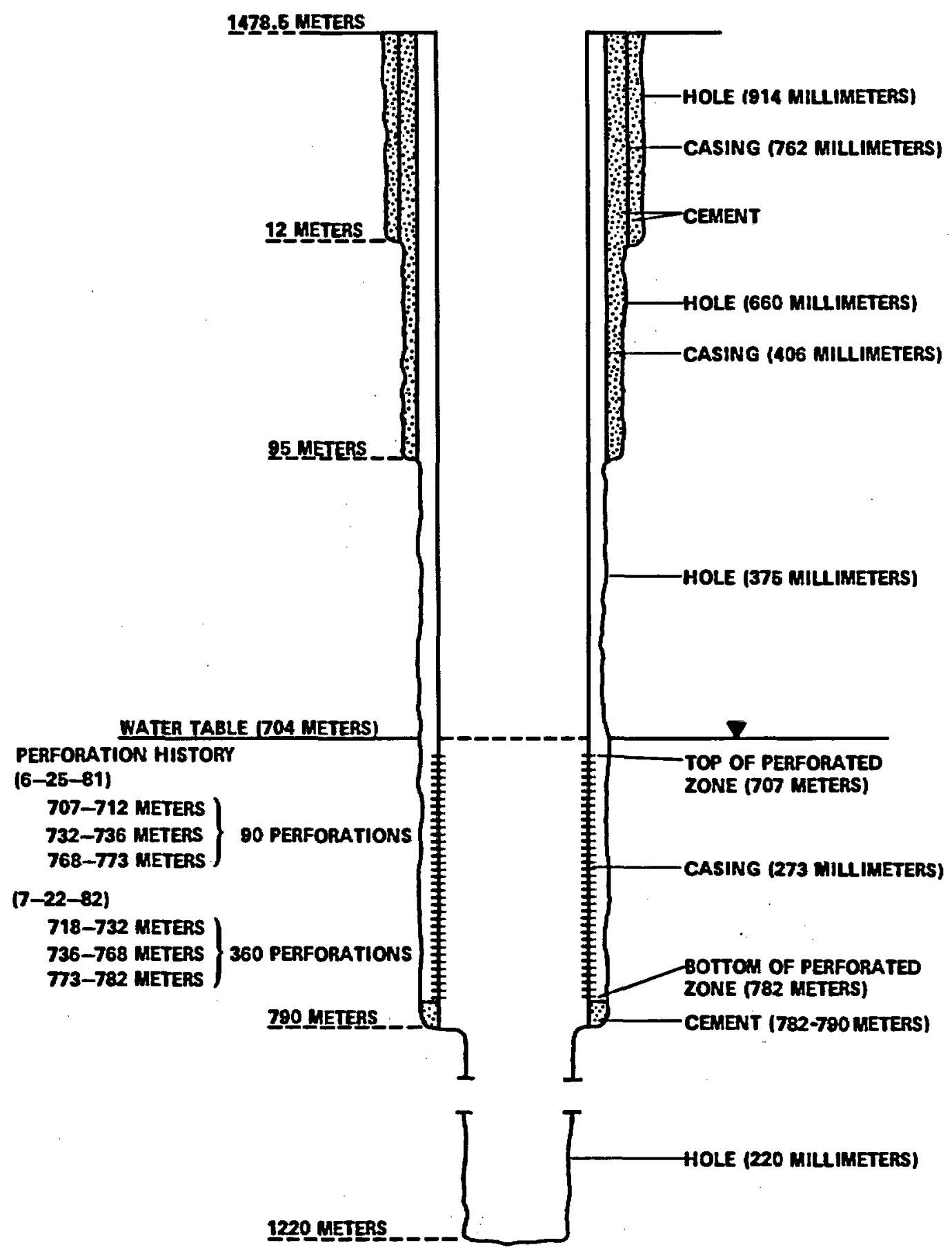

Figure 3.--A typical well construction (well USW H-5). 


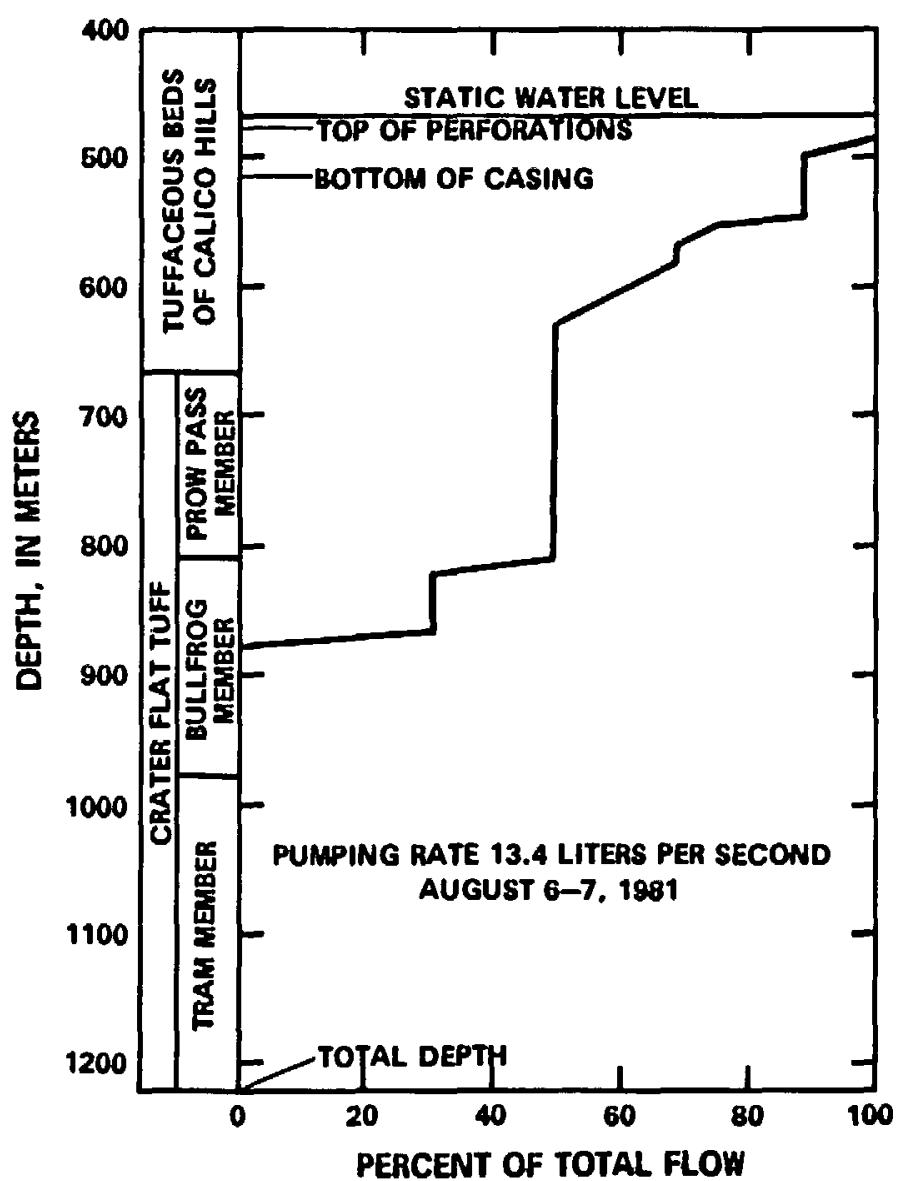

(A) Borohole flow survey in UE-25b\#1

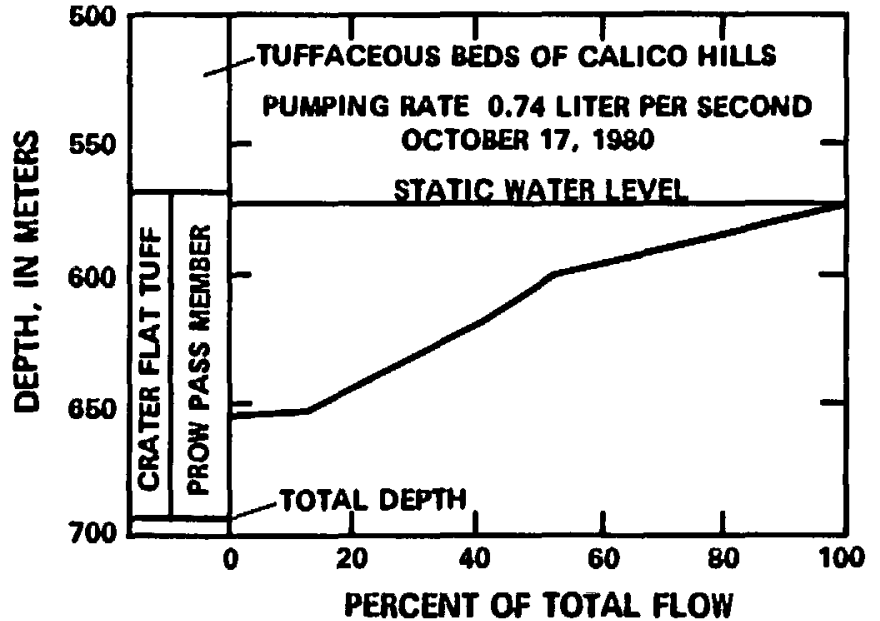

(B) Borehole flow survey in USW H-1, 672 to 688 meters

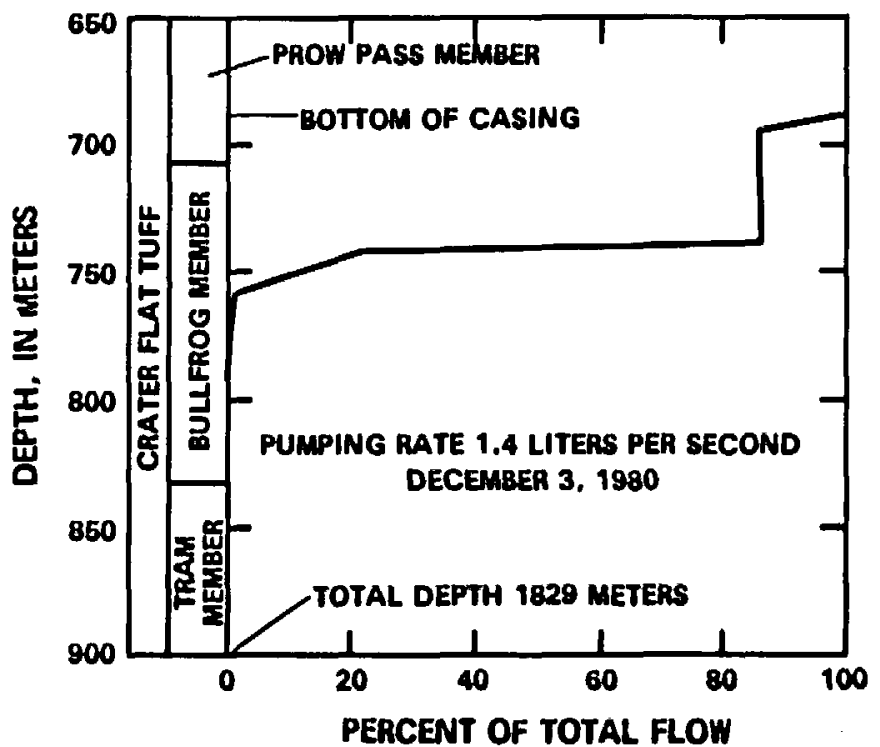

(C) Borehole flow survey in USW H-1, 687 to 1829 motars

Figure 4.--Results of borehole-flow surveys in wells UE-25b非 1 and USW H-1. 


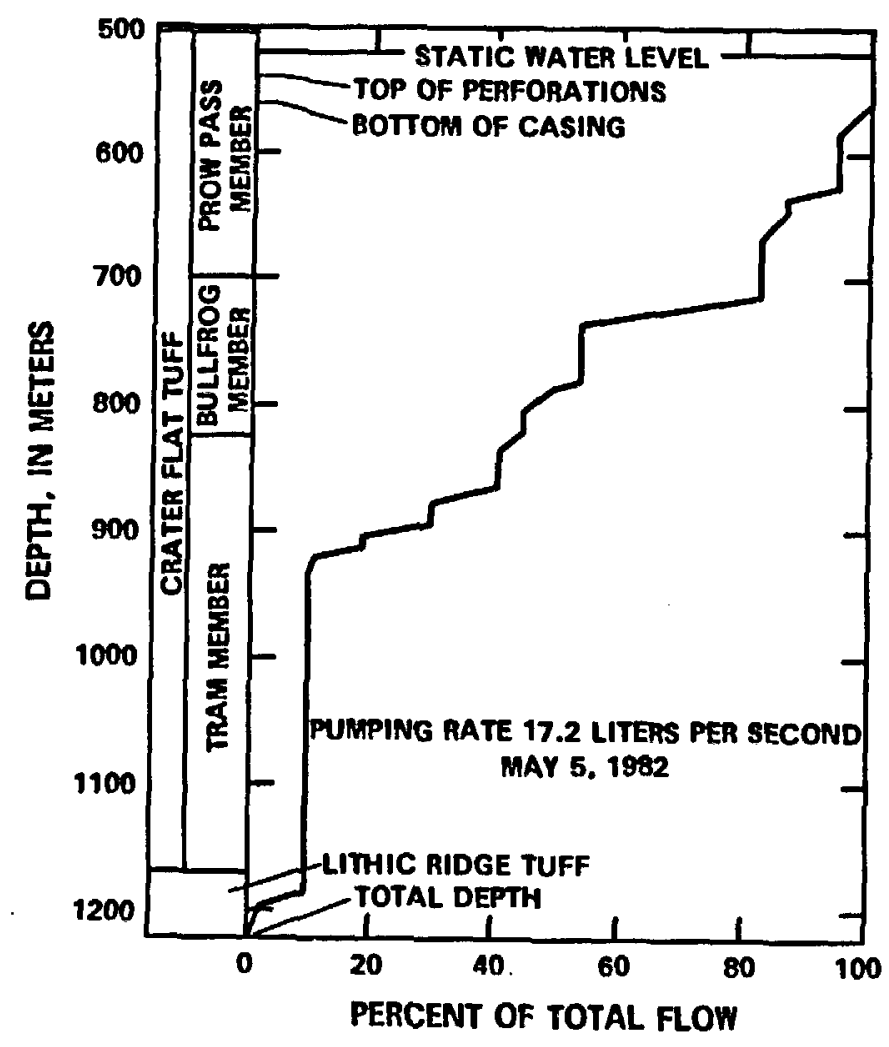

(A) Borehole flow survey in USW $\mathrm{H}-4$

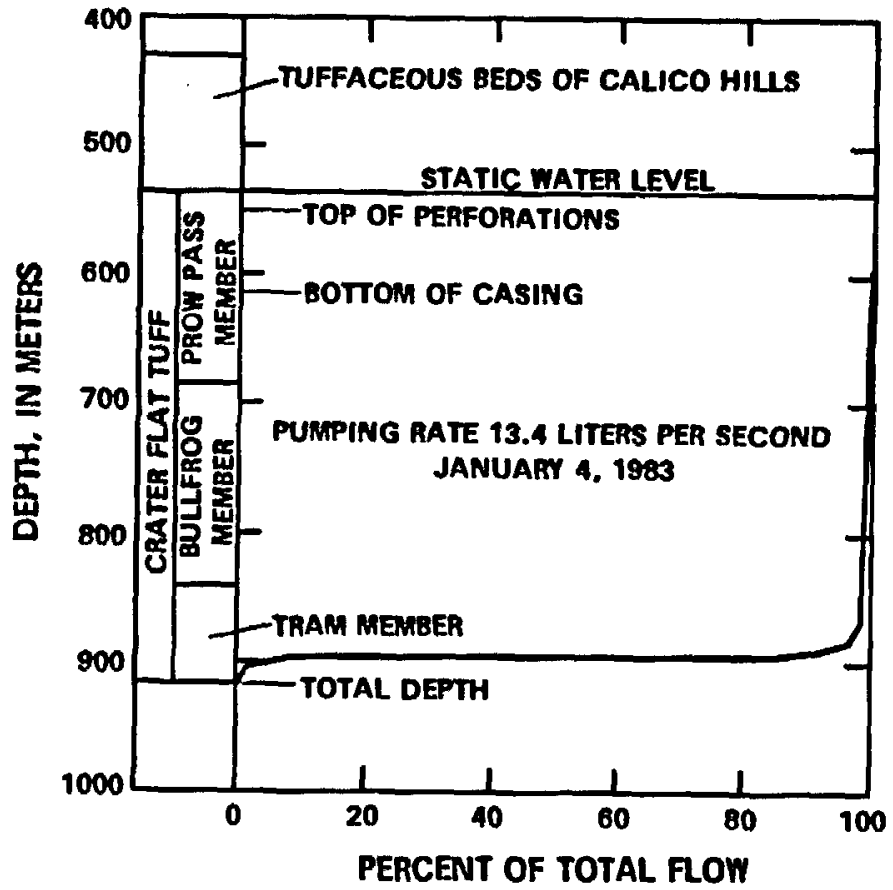

(B) Borehole flow survey in USW G-4

Figure 5.--Results of borehole-flow surveys in wells USW H-4 and USW G-4. 


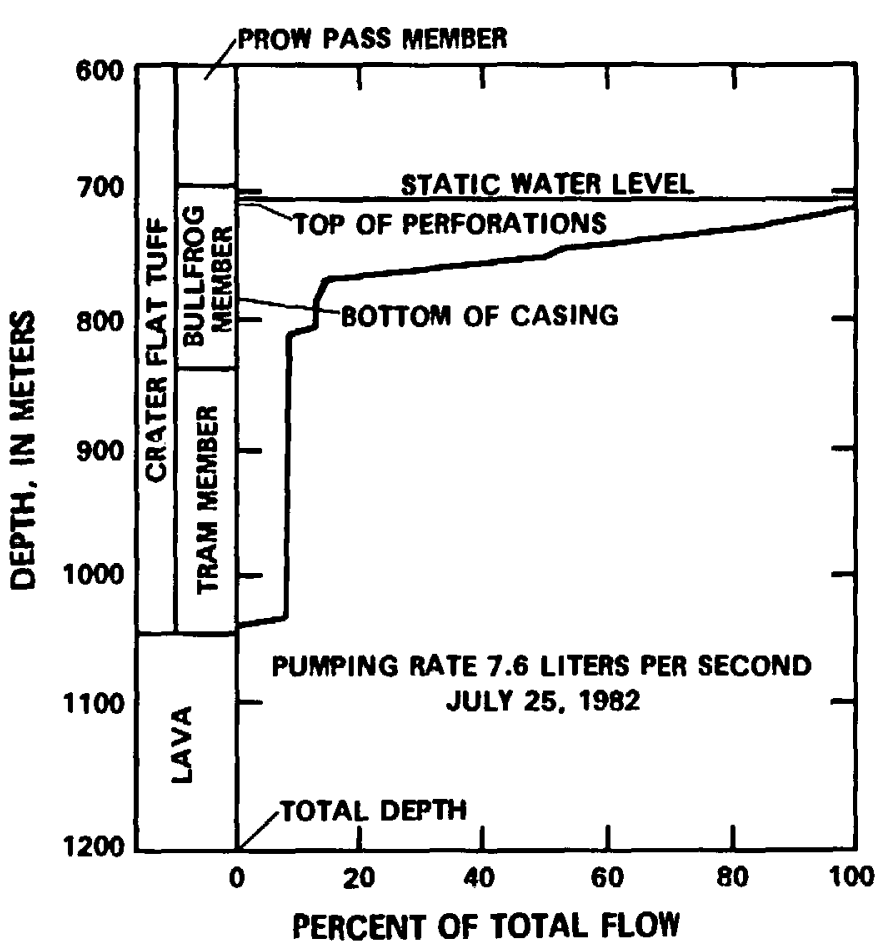

(A) Borehole flow survey in USW H-5

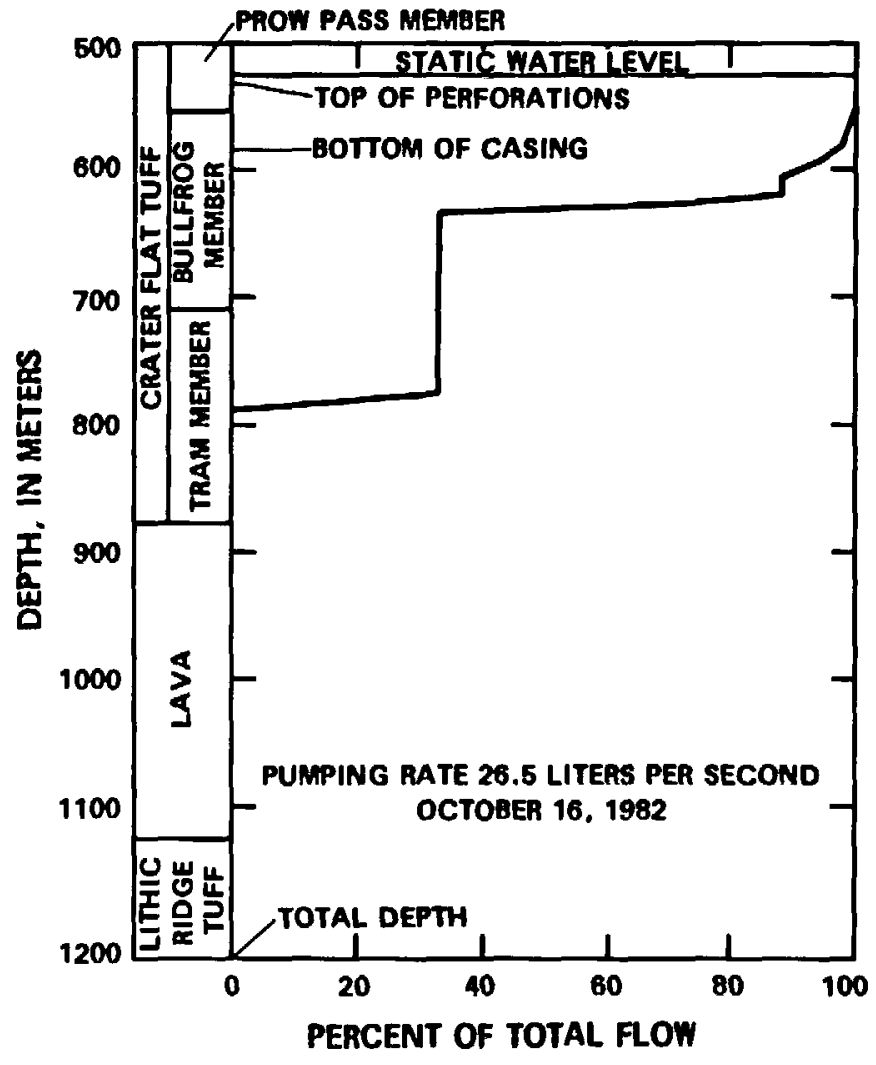

(B) Borehole flow survey in USW H-6

Figure 6.--Results of borehole-flow surveys in wells USW H-5 and USW H-6. 
[m, meters; 80 , del deuterium, reported in parts per thousand, $0 / 00$, relative to SMOW, standard mean ocean water;

$\delta^{18} 0$, del oxygen-18, reported in parts per thousand, $0 / 00$, relative to standard mean ocean water;

$\delta^{13} \mathrm{C}$, del carbon-13, reported in parts per thousand relative to PDB, Peedee belemnite; ${ }^{11} \mathrm{C}, \mathrm{Carbon}^{-14}$;

yr B.P., years before present; HTO, tritium, reported in picocuries per liter; ${ }^{\circ} \mathrm{C}$, degrees Celsius;

dissolved constituents: $\mathrm{Ca}$ (calcium), $\mathrm{Mg}$ (magnesium), $\mathrm{Na}$ (sodium), $\mathrm{HCO}_{3}$ (bicarbonate), $\mathrm{Cl}$ (chloride),

$\mathrm{SO}_{4}$ (sulfate), $\mathrm{SiO}_{2}$ (aqueous silica), and $\mathrm{F}$ (fluoride) reported in milligrams per liter, excepting $\mathrm{Li}$ (lithium) and $\mathrm{Sr}$ (strontium) which are reported in micrograms per 1iter;

- (dash) indicates entire well bore pumped in the case of column five data; otherwise,

- (dash) indicates that no data are available for particular analysis of interest]

\begin{tabular}{|c|c|c|c|c|c|c|c|c|c|c|c|}
\hline $\begin{array}{l}\text { Site } \\
\text { designa- } \\
\text { tion }\end{array}$ & $\begin{array}{l}\text { Land-surface } \\
\text { altitude } \\
\text { (m) }\end{array}$ & $\begin{array}{l}\text { Approximate } \\
\text { wel1 depth } \\
\text { (m) }\end{array}$ & $\begin{array}{c}\text { Approx- } \\
\text { imate } \\
\text { depth } \\
\text { to water } \\
\text { (m) }\end{array}$ & $\begin{array}{l}\text { Interval } \\
\text { sampled } \\
\text { (m) }\end{array}$ & $\begin{array}{l}\text { Collection } \\
\text { date }\end{array}$ & $\begin{array}{l}80 \\
0 / 00 \\
\text { SHOW }\end{array}$ & $\begin{array}{l}6^{180} \\
0 / 00 \\
\text { SMOW }\end{array}$ & $\begin{array}{l}\delta^{13} \mathrm{C} \\
0 / 00 \\
\mathrm{PDB}\end{array}$ & $\begin{array}{c}{ }^{11} \mathrm{C} \\
\text { percent } \\
\text { modern }\end{array}$ & $\begin{array}{c}14 \mathrm{C} \\
\text { apparent } \\
\text { age } \\
\text { (yr B.P.) }\end{array}$ & нто \\
\hline$U E-25 b \| 1$ & $1,200.4$ & 1,220 & 470 & ------ & $08 / 07 / 81$ & -99.5 & -13.4 & -10.7 & $\ldots$ & $\cdots$ & --- \\
\hline UE-25ibf 1 & & & & -..-- & $09 / 01 / 81$ & -101 & -13.4 & -10.4 & 16.7 & 14,400 & $<200$ \\
\hline UE-29a:2 & & & & $\ldots$ & $01 / 15 / 82$ & -93.0 & -12.8 & -13.1 & 60.0 & 4,100 & 37 \\
\hline USW G-4 & $1,270.0$ & 915 & 541 & -........ & $12 / 09 / 82$ & -103 & -13.8 & -9.2 & 22.0 & 12,160 & -- \\
\hline USH H-1 & $1,302.2$ & 1,829 & 572 & $(572-\quad 687)$ & $10 / 20 / 80$ & -103 & -13.4 & $-\ldots-$ & 19.9 & 13,000 & $<\hat{\mathbf{z}} \mathbf{0}$ \\
\hline USW H-1 & & & & $(687-1,829)$ & $12 / 08 / 80$ & -101 & -13.5 & -11.4 & 23.9 & 12,000 & $<20$ \\
\hline USW VH-1 & 954.5 & 762 & 184 & - & $02 / 06 / 81$ & --- & $\cdots$ & $\cdots$ & --- & -...- & $\cdots$ \\
\hline USW VH-1 & & & & - & $02 / 08 / 81$ & --- & --- & ---- & -- & $\cdots+\cdots$ & $\cdots$ \\
\hline USW VH-1 & & & & $-\ldots$ & $02 / 11 / 81$ & -108 & -14.2 & -8.5 & 12.2 & 17,000 & $<20$ \\
\hline$J-12$ & 953.5 & 347 & 225 & $-\ldots-\ldots$ & $03 / 26 / 71$ & -97.5 & -12.8 & -1.9 & 32.2 & 9,100 & $<220$ \\
\hline$J-13$ & $1,011.3$ & 1.063 & 282 & - & $03 / 26 / 71$ & -97.5 & -13.0 & -7.3 & 29.2 & 9,900 & $<220$ \\
\hline
\end{tabular}


Table 1.--Chemical composition of water samples taken from wells in the Yucca mountain area--Continued

\begin{tabular}{|c|c|c|c|c|c|c|c|c|c|c|c|c|c|c|c|}
\hline \multirow{2}{*}{$\begin{array}{c}\text { Site } \\
\text { designa- } \\
\text { tion }\end{array}$} & \multirow{2}{*}{$\begin{array}{c}\text { Onsite } \\
\text { pH } \\
\text { (uirits) }\end{array}$} & \multirow{2}{*}{$\begin{array}{l}\text { Labora- } \\
\text { tory } \\
\text { pll } \\
\text { (units) }\end{array}$} & \multirow{2}{*}{$\begin{array}{l}\text { Water } \\
\text { tempera- } \\
\text { ture } \\
\left({ }^{\circ} \mathrm{C}\right)\end{array}$} & \multicolumn{12}{|c|}{ Dissolved constituents } \\
\hline & & & & $\mathrm{Ca}$ & $\mathrm{Mg}$ & $\mathrm{Na}$ & k & $\begin{array}{r}\mathrm{HCO}_{3} \\
\text { field }\end{array}$ & $\begin{array}{l}\mathrm{HCO}_{3} \\
\text { labor- } \\
\text { atory }\end{array}$ & C. & $\mathrm{SO}_{4}$ & $\mathrm{SiO}_{2}$ & Li & $S r$ & $\mathbf{F}$ \\
\hline$U E-25 b H L$ & 7.1 & 6.8 & 36.0 & 19 & 0.73 & 53 & 3.7 & 173 & 158 & 13 & 24 & 53 & 950 & 44 & 1.5 \\
\hline UE-25b\#1 & 7.5 & 7.5 & 36.0 & 17 & .59 & 46 & 3.5 & 139 & 134 & 8.5 & 22 & 52 & 220 & 38 & 1.6 \\
\hline UE-25bH 1 & 7.1 & 7.7 & 37.2 & 18 & .72 & 46 & 2.8 & 133 & 138 & 7.5 & 21 & 51 & 120 & 47 & 1.6 \\
\hline UE-29a\#2 & 7.2 & 7.6 & 25.1 & 10 & .2 & 44 & 1.1 & 107 & 112 & 11 & 22 & 44 & 100 & 39 & 1.0 \\
\hline UE-29a\#2 & 7.0 & 7.4 & 22.7 & 10 & .3 & 44 & 1.3 & 107 & 110 & 8.8 & 21 & 44 & 110 & 33 & .9 \\
\hline USW $\mathrm{H}-1$ & 7.7 & 7.8 & 33.0 & 4.5 & $<.1$ & 51 & 2.4 & -- & 115 & 5.7 & 18 & 47 & 40 & 5 & 1.2 \\
\hline USW G-4 & 7.7 & 7.5 & 35.6 & 13 & .2 & 57 & 2.1 & 139 & 143 & 5.9 & 19 & 45 & 67 & 17 & 2.5 \\
\hline USW H-1 & 7.5 & 8.0 & 34.7 & 6.2 & $<.1$ & 51 & 1.6 & $\cdots$ & 122 & 5.8 & 19 & 40 & 40 & 20 & 1.0 \\
\hline USW H-4 & 7.4 & 7.9 & 34.8 & 17 & .29 & 73 & 2.6 & 173 & 171 & 6.9 & 26 & 46 & 130 & 27 & 4.8 \\
\hline USW H-5 & 7.8 & 7.8 & 36.5 & 1.9 & .01 & 60 & 2.1 & 126 & 124 & 6.1 & $1 \overline{6}$ & 48 & 62 & 9 & 1.4 \\
\hline USW H-5 & 7.9 & 8.0 & 35.3 & 2.0 & $<.01$ & 60 & 2.1 & 127 & 12.4 & 6.1 & 16 & 48 & 71 & 4 & 1.4 \\
\hline USW H-6 & 8.1 & 8.3 & 37.8 & 4.1 & .09 & 86 & 1.3 & 182 & 188 & 7.6 & 29 & 48 & 82 & 8 & 4.7 \\
\hline USW VII- 1 & 7.9 & 8.0 & 35.2 & 11 & 1.6 & 79 & 1.9 & 167 & 158 & 11 & 44 & 50 & 90 & 70 & 2.7 \\
\hline USW VH-1 & 7.5 & 7.9 & 35.5 & 10 & 1.5 & 80 & 1.9 & 165 & 158 & 10 & 45 & 50 & 90 & 70 & 2.7 \\
\hline USW VII-1 & 7.5 & 8.0 & 35.5 & 9.9 & 1.5 & 78 & 1. 8 & 162 & 158 & 10 & 44 & 49 & 90 & 60 & 2.7 \\
\hline $\mathrm{J}-12$ & 7.1 & -- & 27.0 & 14 & 2.1 & 38 & 5.1 & $\cdots$ & 113 & 7.3 & 22 & 54 & 40 & 10 & 2.1 \\
\hline $3-13$ & 7.2 & -- & 31.0 & 12 & 2.1 & 42 & 5.0 & -- & 124 & 7.1 & 17 & 57 & 10 & 20 & 2.4 \\
\hline
\end{tabular}


More than one analysis is shown for wells UE-25b\#1, USW H-1, USW VH-1, and UE-29a\#2. The multiple analyses permit a comparison of water compositions as a function of volume of water pumped. The sample obtained on July 20, 1982, from UE-25b\#1 was collected after 28 days of pumping of an interval 863 to $875 \mathrm{~m}$ below the land surface (Daniels and others, 1982). This interval was isolated using inflatable packers. Well USW $H-1$ was first sampled on October 20, 1980, after drilling to a depth of $687 \mathrm{~m}$; the hole then was cased and tack cemented from 677 to $687 \mathrm{~m}$, deepened to $1,829 \mathrm{~m}$, and a water sample was obtained on December 8, 1980, while pumping the interval from 687 to $1,829 \mathrm{~m}$.

Plots of relative cation and anion concentrations in Yucca Mountain ground water (fig. 7) indicate that sodium and bicarbonate ions are the predominant cation and anion. However, ground water in the Yucca Mountain area is not chemically homogeneous (figs. 8 and 9). The chemical composition of ground water from well UE-29a\#2 is characterized by low concentrations of soaium, potassium, bicarbonate, and fluoride and a high concentration of chloride relative to the compositions of other ground water in the Yucca Mountain area. Ground water from well UE-29a\#2 is isotopically light with respect to $\delta^{180}$ (del oxygen-18) and $\delta D$ (del deuterium); its uncorrected ${ }^{14 C}$ (carbon-14) age is the youngest of all ground water in the area (fig. 10). Ground water from well $\mathrm{J}-12$ and well $\mathrm{J}-13$ have low concentrations of sodium and high concentrations of potassium, magnesium, calcium, and fluoride (figs. 8 and 9). These ground-water samples are isotopically heavy with respect to $\delta^{18} 0, \delta D$, and $\delta^{13} \mathrm{C}$ (del carbon-13); the uncorrected ${ }^{14} \mathrm{C}$ ages of these samples are relatively young (fig. 10). Ground water from wells USW H-4 and USW H-6 is characterized by low concentrations of sodium, bicarbonate, sulfate, and fluoride (figs. 8 and 9); ground water from these wells is isotopically light with respect to $\delta^{13} \mathrm{C}$ and $6 \mathrm{D}$. The uncorrected ${ }^{14} \mathrm{C}$ age of ground water from well USW H-4 is the oldest of all ground water from the Yucca Mountain area. Ground water from well USW VH-1 has low concentrations of sodium, magnesium, bicarbonate, sulfate, chloride, and fluoride; the water is isotopically light with respect to $\delta^{180}$ and $\delta D$, and it has the second oldest uncorrected ${ }^{14} C$ age.

\section{FLOW SURVEYS}

Flow surveys were conducted in those wells near the periphery of the Yucca Mountain exploratory block. Results of these surveys indicate that fluid production usually is from a few discrete permeable intervals (figs. 4 to 6). Exceptions to this generalization are evident in the flow-survey data for well USW H-4 (fig. 5A) and well USW H-5 (fig. 6A). In well USW H-4, the majority of fluid production came from numerous zones throughout the upper one-half of the saturated interval penetrated by the borehole. In well USW H-5, fluid production in the upper one-half of the Bullfrog Member of the Crater Flat Tuff of Tertiary age also was associated with numerous zones. Borehole flow-survey data also indicate that for well UE-29a\#2 production principally was from rhyolitic lavas of the Tuffaceous beds of Calico Hills of Tertiary age (R. K. Waddell, U.S. Geological Survey, written commun., 1983). Water injection tests using packers indicate that most of the production in wells J-12 and J-13 comes from the Topopah Spring Member of the Paintbrush Tuff of Tertiary age (Young, 1972; William Thordarson, U.S. Geological Survey, 


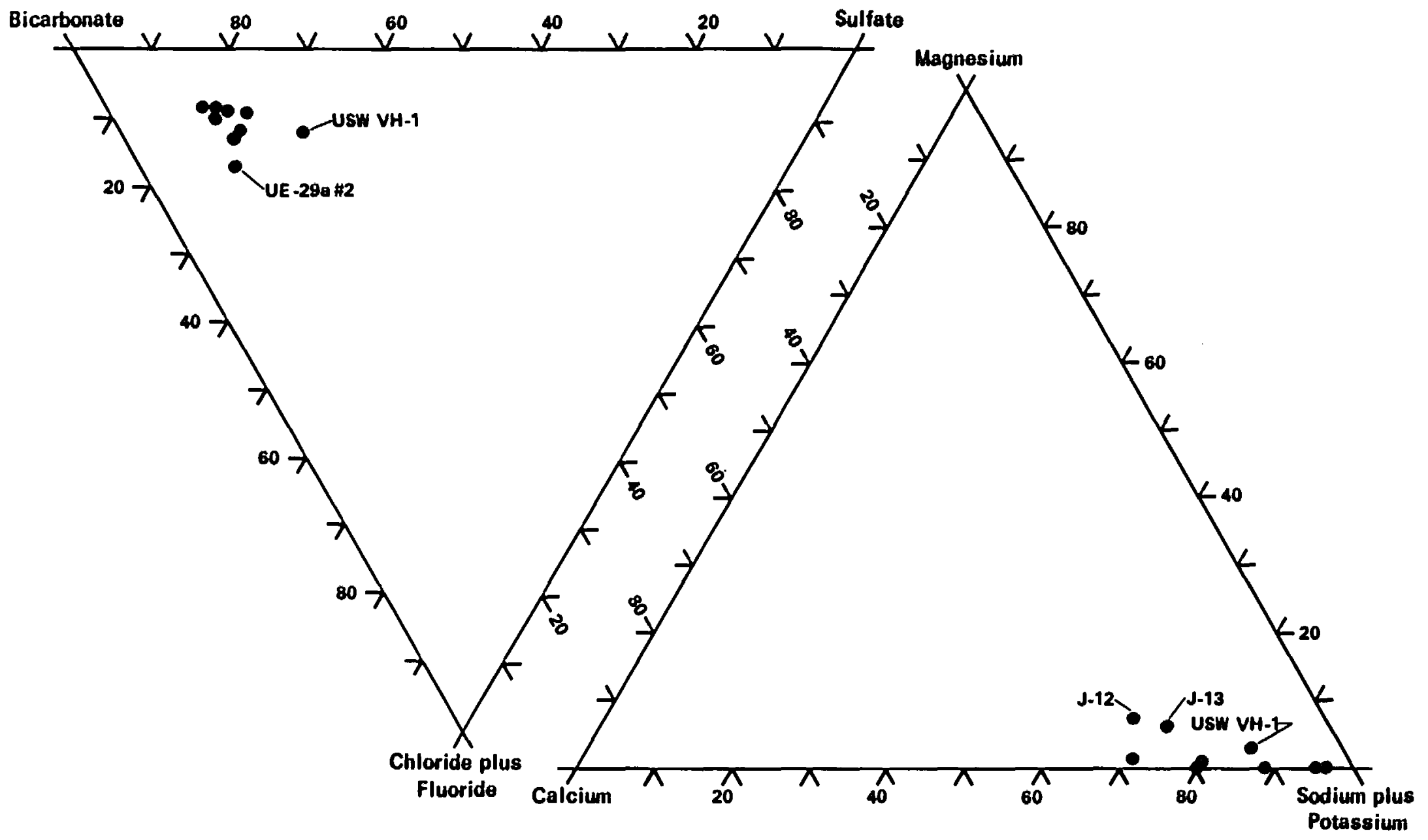

Figure 7.--Relative cation and anion concentrations (equivalent fractions) of ground water from the Yucca Mountain area. 

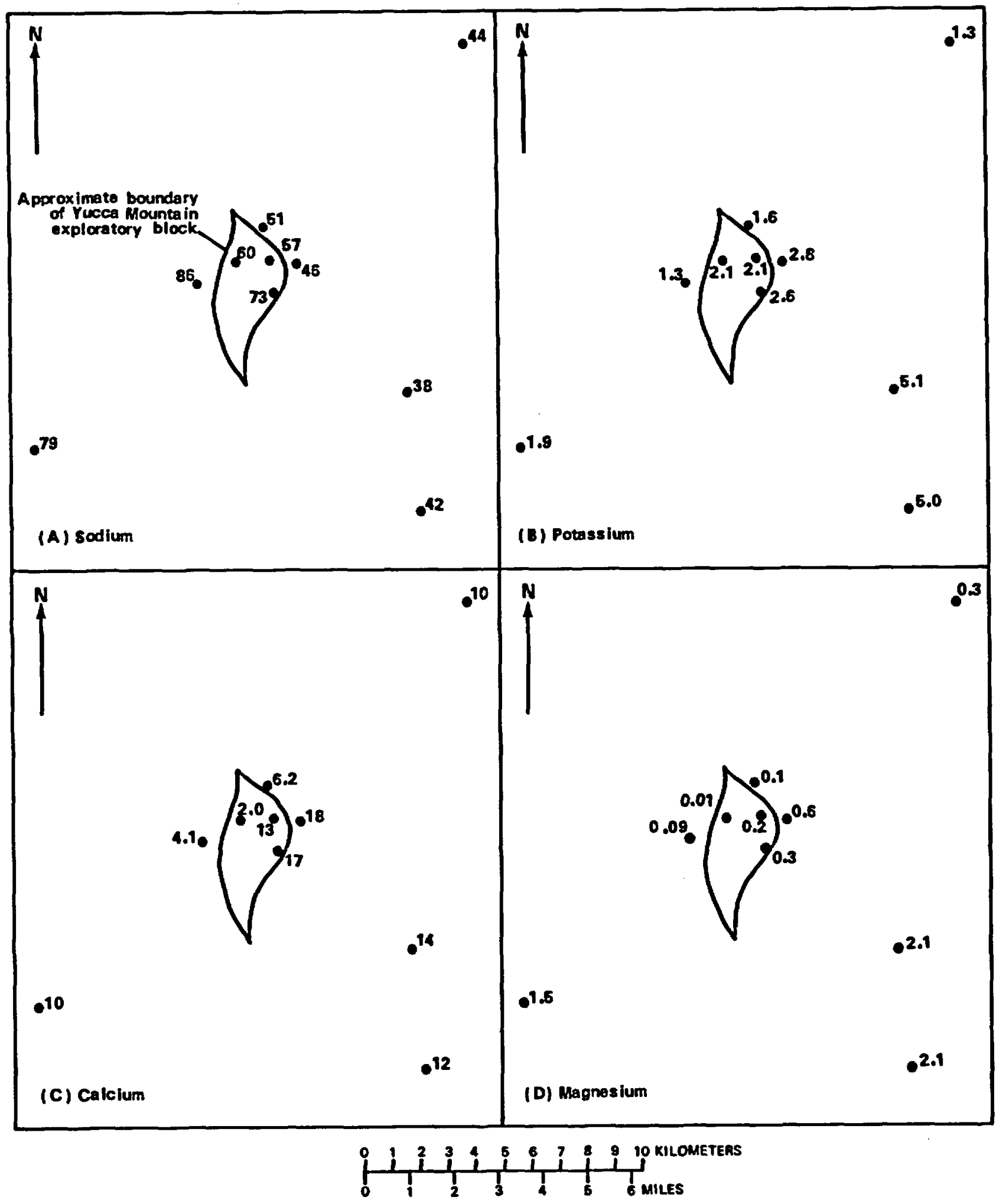

Figure 8.--Sodium, potassium, calcium, and magnesium concentrations, in milligrams per liter, in ground water from the Yucca Mountain area. 

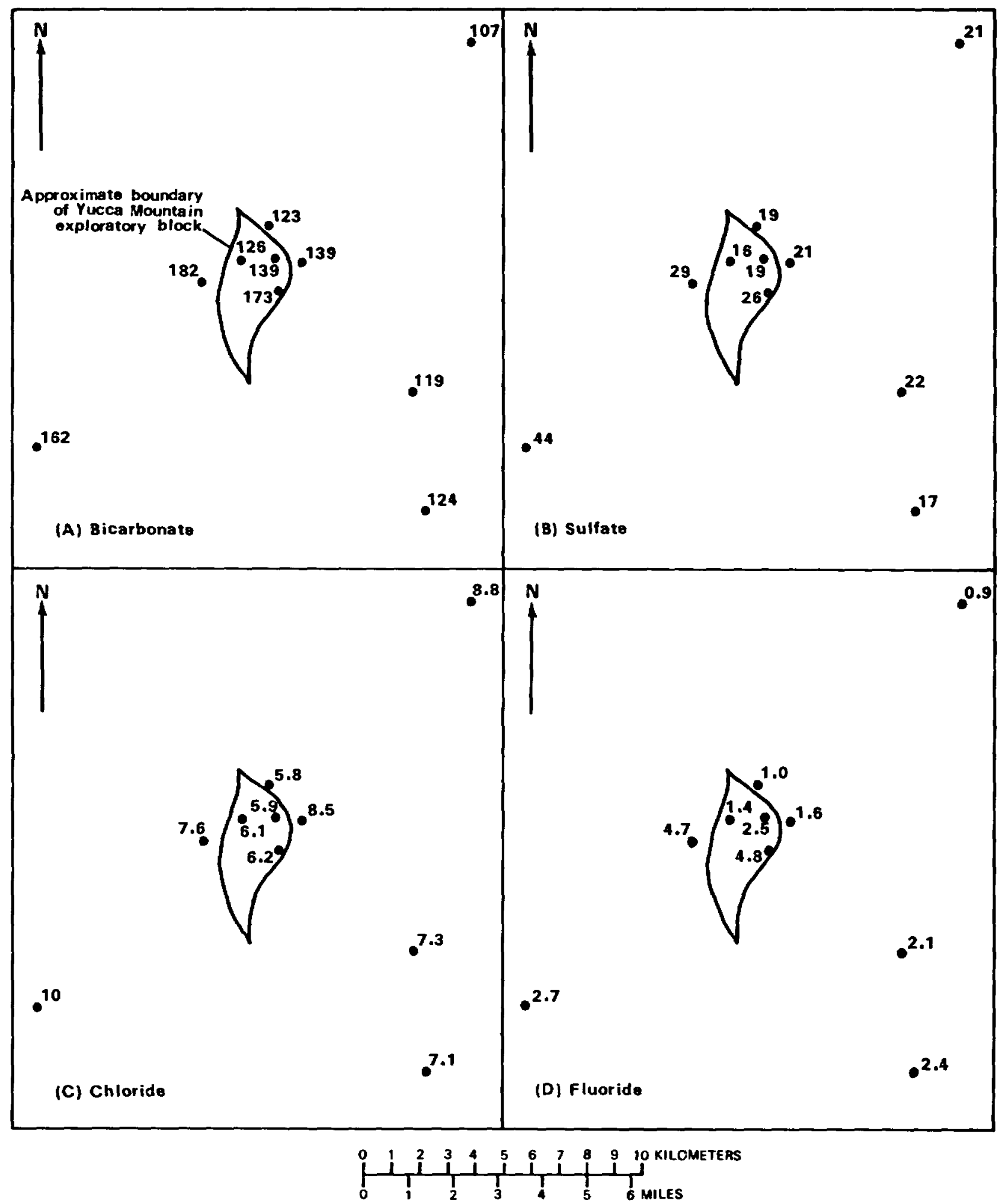

Figure 9.--Bicarbonate, sulfate, chloride, and fluoride concentrations, in milligrams per liter, in ground water from the Yucca Mountain area. 

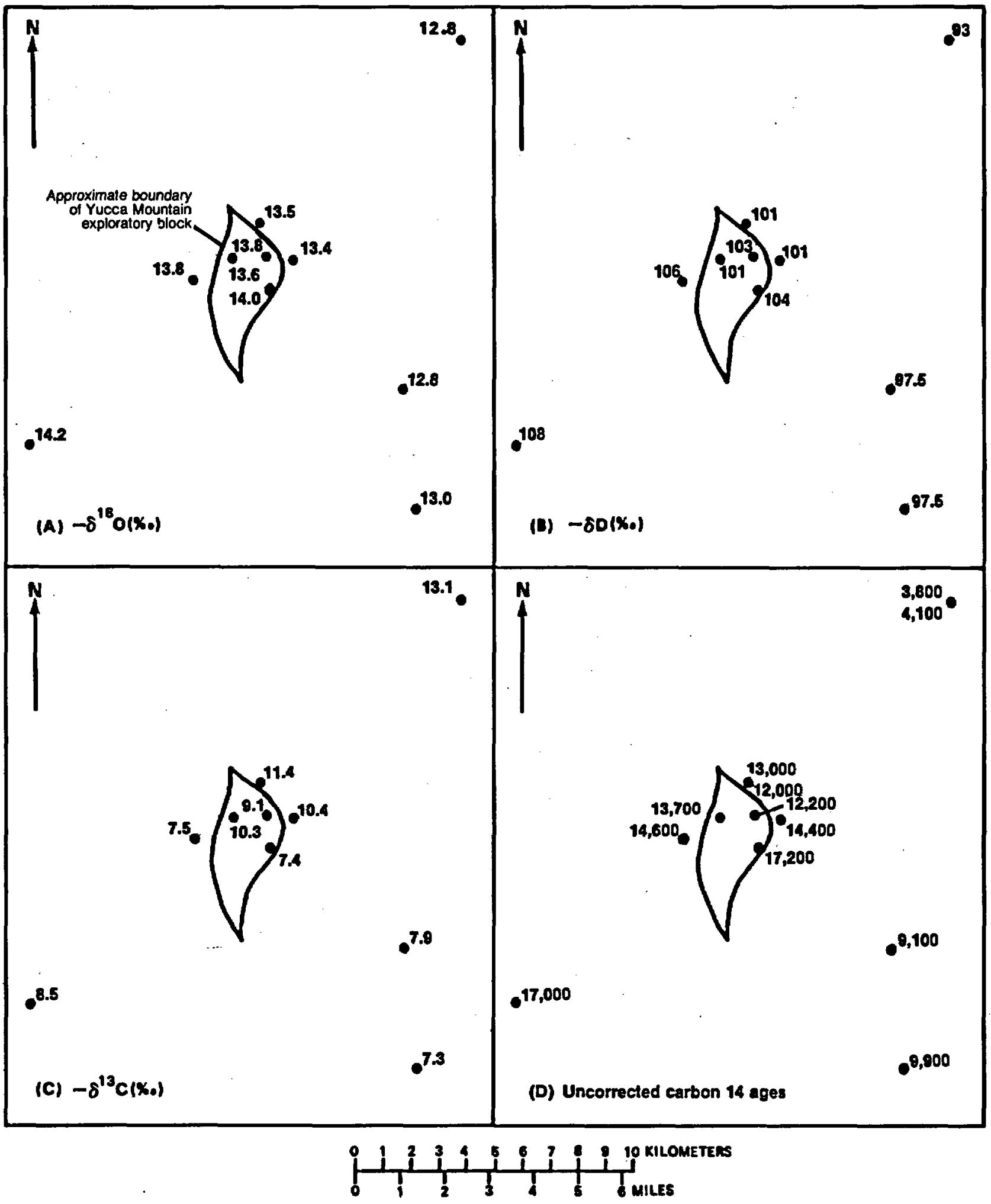

Figure 10.--Del oxygen-18 $\left(\delta^{18} 0\right)$, del deuterium $(\delta \mathrm{D})$, del carbon-13 $\left(\delta^{13} \mathrm{C}\right)$, and uncorrected carbon-14 ( $\left.{ }^{14} \mathrm{C}\right)$ ages for ground water from the Yucca Mountain area. 
written commun., 1983), and that all of the production in well VH-1 comes from the Bullfrog Member of the Crater Flat Tuff of Tertiary age (Lewis Howells, U.S. Geological Survey, written commun., 1983).

A summary diagram showing the vertical distribution of permeable zones in wells in the Yucca Mountain area (fig. 11) indicates little or no well-to-well correlation of permeable zones with lithology. However, permeable intervals commonly occur near the water-table surface regardless of the geologic unit.

\section{DISCUSSION}

\section{Representativeness of Ground-Water Samples}

One criterion used to judge the representativeness of a ground-water sample is the lessening of drilling-fluid tracer concentrations to values approximating those of uncontaminated ground water. A substance chosen to be a tracer of drilling fluid needs to have the following characteristics:

1. The tracer needs to be easily detectable even when dilution processes decrease its concentration by a factor of $10^{-3}$;

2. Only trace concentrations of the tracer should be present in the natural ground water; and

3. The tracer should not react chemically with solids lining fluid pathways.

Lithium has the first two characteristics, but it sorbs on negatively charged mineral surfaces; however, this process probably is reversible in nature because the lithium desorbs from mineral surfaces as drilling fluid and ground water are pumped from the we11. Therefore, the measured concentration of lithium in pumped waters should nearly reflect the extent of drilling-fluid contamination.

Measured lithium concentrations ranged from 40 to $950 \mu \mathrm{g} / \mathrm{L}$ (table 1 ). The percentage of drilling-fluid contamination, as a function of the lithium concentration in the formation-water and the drilling-fluid mixture, is shown in figure 12. A comparison of the lithium data of table 1 with figure 12 indicates that only the samples collected on August 7, 1981, from well UE-25b\#1 had a drilling-fluid contamination in excess of 1.0 percent; the majority of samples contain less than about 0.4 percent drilling fluid. The effect of drilling-fluid contamination on measured ground-water chemical composition is minimized further by the overall similarity in chemical composition of drilling fluid and other ground water in the Yucca Mountain area.

\section{Chemical Inhomogeneity of Yucca Mountain in Ground Water}

Data presented in this report (figs. 8 to 10 ) indicate that ground water from wells in the Yucca Mountain area has a small degree of lateral chemical 


\begin{tabular}{|c|c|c|c|c|c|c|c|}
\hline \multirow{2}{*}{ FORMATION } & \multicolumn{7}{|c|}{ WELL NUMBER } \\
\hline & $\begin{array}{l}\text { USW } \\
H-6\end{array}$ & $\begin{array}{l}\text { USW } \\
H-5\end{array}$ & $\begin{array}{l}\text { USW } \\
\mathrm{H}-1\end{array}$ & $\begin{array}{l}\text { USW } \\
\text { G-4 }\end{array}$ & $\begin{array}{l}\text { USW } \\
H-4\end{array}$ & $\underset{26 b \# 1}{\text { UE- }}$ & $\begin{array}{l}\text { J. } \\
13\end{array}$ \\
\hline Topopah Spring Member of Paintbrush Tuff & & & & & & & $\frac{w}{m}$ \\
\hline Tuffacoous beds of Calico Hills & & & wT & $\mathbf{w T}$ & & $\frac{W T}{2}$ & \\
\hline Prow Pass Member of Crater Flat Tuff & $\mathbf{w T}$ & vT & & & $\boldsymbol{w r}$ & & \\
\hline Bulferog Momber of Crater Flat Tuff & 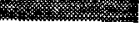 & 2. & 6ix & & & & \\
\hline Tram Member of Crator Flat Tuff & TD & & To & $\pi$ & & TD & \\
\hline Lava & & & & & & & \\
\hline Tuff of Lithic Ridgo & & & & & TD & & TD \\
\hline WT - Water toble & $\pi$ & depth & & & oable & & \\
\hline
\end{tabular}

Figure 11.--Vertical distribution of permeable zones in selected wells in the Yucca Mountain area. 


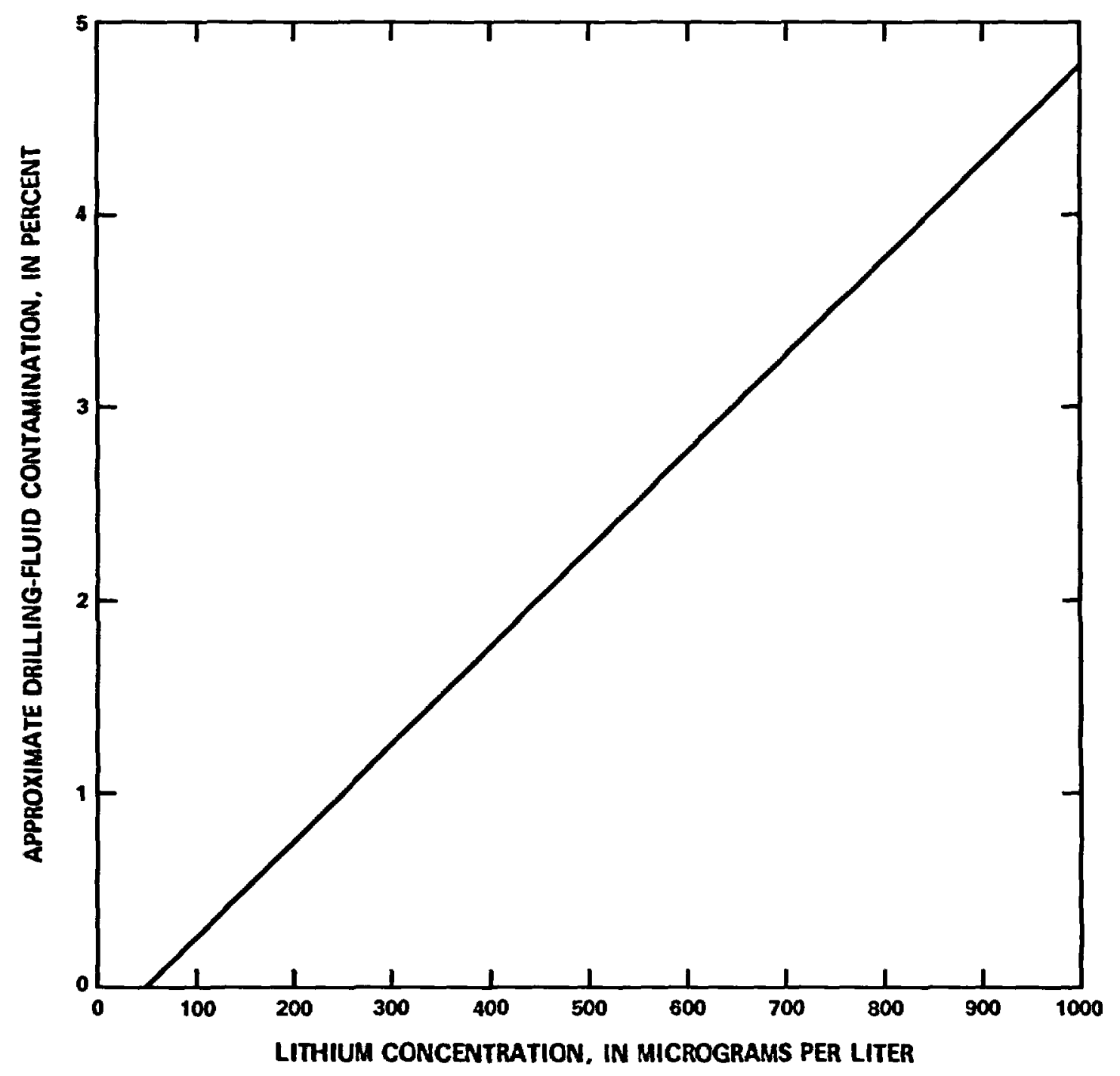

Figure 12.--Plot of drilling-fluid contamination as a function of lithium concentration. 
variability. Future work is planned to test the degree of vertical chemical homogeneity of ground water from several wells located within the exploratory block.

\section{REFERENCES}

Blankennagel, R. K., 1967, Hydraulic testing techniques of deep drill holes at Pahute Mesa, Nevada Test Site: U.S. Geological Survey open-file report, $50 \mathrm{p}$.

Brown, Eugene, Skougstad, M. W., and Fishman, M. J., 1970, Methods for collection and analysis of water samples for dissolved minerals and gases: U.S. Geological Survey Techniques of Water-Resources Investigations, Book 5, Chapter A1, $160 \mathrm{p}$.

Caporuscio, F., Vaniman, D., Bish, D., Broxton, D., Arney, B., Heiken, G., Byers, F. , Cooley, R., and Semarge, E., 1982, Petrologic studies of drili cores USW-G2 and UE25b-1H, Yucca Mountain, Nevada: Los Alamos National Laboratory Report LA-9255-MS, 111 p.

Claassen, H. C., 1973, Water quality and physical characteristics of Nevada Test Site water-supply wells: U.S. Geological Survey Report USGS-474-158, available only from Technical Information Service, Springfield, VA 22161, $145 \mathrm{p}$.

Daniels, W. R., Erdal, B. R., and Vaniman, D. I., 1982, Research and development related to the Nevada Nuclear Waste Storage Investigations: Los Alamos National Report LA-9577-PR, $60 \mathrm{p}$.

Thatcher, L. L., Janzer, V. J., and Edwards, K. W., 1977, Methods for determination of radioactive substances in water and fluvial sediments: U.S. Geological Survey Techniques of Water-Resources Investigations, Book 5, Chapter A5, 95 p.

Young, R. A., 1972, Water supply for the Nuclear Rocket Development Station at the U.S. Atomic Energy Commission's Nevada Test Site: U.S. Geological Survey Water-Supply Paper 1938, 19 p. 
